\title{
DISCRETIONARY ADMINISTRATIVE JURISDICTION OF THE NLRB UNDER THE TAFT-HARTLEY ACT*
}

The National Labor Relations Board has power to adjudicate labor disputes “affecting commerce" coterminous with Congress' own authority to regulate commerce. ${ }^{1}$ But the Board has never attempted to exercise this power to the legal limit. Instead, it has declined jurisdiction over some industries or disputes on the ground that they are "essentially local in character"' and that to assert jurisdiction would not "effectuate the purposes or policies of the act."'3

By making certain union activities unfair labor practices, ${ }^{4}$ however, the

* Joliet Contractors Association v. NLRB, 193 F.2d 833 (7th Cir. 1952).

1. The general constitutional theory is that the statutory language "affecting commerce" gives to the administrative agency the broadest grant of power possible under the Constitution. NLRB v. Fainblatt, 306 U.S. 601, 607 (1939) (commerce power extends to clothing industry); Consolidated Edison Co. v. NLRB, 305 U.S. 197, 205 (1938) (public utility); NLRB v. Jones \& Laughlin Steel Corp., 301 U.S. 1, 31, $34-7$ (1937) (steel manufacturer). See also Stern, The Commerce Clause and the National Economy, 1933-1946, 59 HARv. L. REv. 645, 883, at 670-2, 679-85, 905-07, 909-25, $945-7$ (1946).

2. Under the original Wagner Act, 49 STAT. 449 (1935), 29 U.S.C. $\$ \S 151-66$ (1946), the Board generally declined jurisdiction over industries essentially local in character: McDonald Cooperative Dairy Co., 58 N.L.R.B. 552 (1944) (dairy industry) ; Yellow Cab \& Baggage Co., 17 N.L.R.B. 469 (1939) (local taxicab company); Remington Rand, Inc., 27 N.L.R.B. 488 (1940) (service division of interstate corporation); Hotel Ass'n of St. Louis, 92 N.L.R.B. 1388 (1951) (reaffirming 15-year policy of denying jurisdiction in hotel industry); Chicago Motor Coach Co., 62 N.L.R.B. 890 (1945) (local transit line); Cousins Tractor Co., 72 N.L.R.B. 857 (1947) (local sales and service agency) ; S. \& R. Baking Co., 65 N.L.R.B. 351 (1946) (bakery); Hubby-Reese Co., 72 N.L.R.B. 1404 (1947) (wholesale grocery); Brown \& Root, 51 N.L.R.B. 820 (1943) (construction industry); Johns-Manville, 61 N.L.R.B. 1 (1945) (construction). But cf. Brown Shipbuilding Co., 57 N.L.R.B. 326 (1944) (jurisdiction accepted in case involving construction workers regularly employed in shipyard).

For extensive summaries of industries within and without the pale of federal regulation, see Walsh, "Local Business," 1 LAB. L.J. 783 (1950); Schwartz, Local BusincssNo Man's Land in Labor Relations 1 LAB. L.J. 189 (1949); Feldblum, Jurisdictional "Tidelands" in Labor Relations, 3 LAB. L.J. 114 (1952).

3. This position has been upheld in the past by courts. In Haleston Drug Stores v. NLRB, 187 F.2d 418, 421 (9th Cir.), cert. denied, 342 U.S. 815 (1951) (upholding Board's rejection of jurisdiction over chain stores, where union petitioning for election), the Ninth Circuit said that the Board could, "for reasons of policy or for budgetary or for other reasons," decline jurisdiction after a complaint had issued. Sce NLRB v. Denver Bldg. \& Construc. Trades Council, 341 U.S. 675, 684 (1951) ("[T]he Board sometimes properly declines to [take jurisdiction] stating that the policies of the act would not bo effectuated in that case," even though the activities affect commerce). And see NLRB v. Newark Morning Ledger Co., 120 F.2d 262 (3d Cir.), cert. denied, 314 U.S. 693 (1941).

4. 61 STAT. 136 (1947), 29 U.S.C. \& 158(b) (Supp. 1952). The Act makes illegal the following union practices: coercion of employees or employers; discrimination against 
Taft-Hartley Act of $1947^{5}$ complicated the problem of NLRB jurisdiction. Now the Board was forced to handle additional problems in the industries that it had previously regulated. Furthermore, some of the newly-illegal union practices existed primarily in areas where formerly the Board had refused to exercise jurisdiction. ${ }^{6}$ If the NLRB had continued its previous jurisdictional policy, many of the new proscriptions would have been rendered meaningless. On the other hand, if the Board had accepted all cases involving such union unfair labor practices, the increased case-load would have been far greater than it could handle. ${ }^{7}$

Because Congress had provided no new guide for the exercise of NLRB authority, 8 the Board, in a series of unanimous decisions in October of 1950 ,

an employee; failure to bargain collectively; secondary boycotts and jurisdictional disputes; excessive union dues; and featherbedding. Section $158(3)(3)$ bans the elossd shop. The role of the Board was thus changed from that of a booster of organized labor to a mediator between labor and management. See NLRB, LEGISLATTVE HisTonY or trEE Labor MIANagemient Relations Act of 1947, fassim (1918) (hereinafter citcd as Lesis-

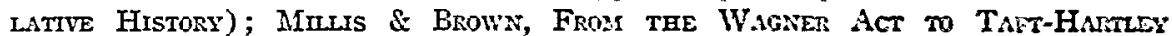
271, 314-15, 655-65, c.12 (1950) (hereinafter cited as MruLrs). Sce also Title II of the Labor Management Relations Act of 1947, 61 Stix. 136 (1947), 29 U.S.C. $\$ \$ 171-\$ 2$ (Surp. 1952), establishing the Federal Mediation and Conciliation Service, particulariy 29 U.S.C. $\$ 171$ (Supp. 1952) (declaration of purpose and policy).

5. Labor Management Relations Act of 1947, 61 Sт.1T. 136 (1947), 39 U.S.C. § 141 (Supp. 1952).

6. Prior to Taft-Hartley, the Board, for example, had refused to assert cuntrol over the building trades because of the segmentation of the industry, the interstate, intermittent and migratory character of the work, and the fact that unions there were already well-entrenched. But in this industry, newly-illegal union practices-such as juriedictional disputes, secondary boycotts, and featherbedding-were notoriously common. Sce, Covington, Jurrisdiction of the National Labor Relations Board ouer the Butlding and Construction Industry, 28 N.C.L. Rev. 1, 2 (1949); Comment, The Insat of the TaftHartley Act on the Building and Construction Indtustry, G0 Yaxe L.J. 673, 674 (1951); Rosenthal, Labor Board Jurisdiction ozer the Building and Construction Industry, 3 Lan. L.J. 7 (1952). See also IIruus 401-02.

7. See notes 31 and 35 infra.

8. The original National Labor Relations Act, or Wagner Act, 49 StAт. 449 (1935), 29 U.S.C. $\$ 160$ (a) (1946), stated: "The Board is cmpouicred . . to prevent any person from engaging in any unfair labor practice ... a affecting commerce" (Emphasis added). The Taft-Hartley Act, 61 Stat. 136 (1947), 29 U.S.C. $\$ 160$ (a) (Supp. 1952), mal:es no change. Courts generally have seized on this language to justify the discretionary jurisdiction of the Board. In Haleston Drug Stores v. NLRB, 187 F.2d 418, 421 (9th Cir.), cert. denied, 342 U.S. 815 (1951), the court stated that "[b]y the express language of $\$ 10$ (a) [29 U.S.C. $\S 160$ (a) (Supp. 1952)] the Board was and still is empouxcred (not directed) to prevent persons from engaging in unfair labor practices affecting commerce. Its discretionary authority in respect of its assertion of jurisdiction was never, so far as we are informed, questioned under the act as it existed prior to 1947." See also NLRB v. Newark Morning Ledger Co., 120 F.2d 262, 268-9 (3d Cir.), cert. dcrsicd, 314 U.S. 693 (1941). And see Goodman \& Griggs, Jurisdiction of NLRB Under Self-Imposed Limitations, 50 MIICH. L. REv. 899 (1952). 
announced jurisdictional yardsticks applicable to all industries. ${ }^{0}$ The Board would hear only those disputes likely to affect defense production or to lead to a serious interruption in the flow of goods in commerce. And the impact on commerce would be measured by the dollar volume of transactions through interstate channels by the company or companies involved. In no sense were these standards intended to define the legal limits of the Board's power to hear disputes. Rather, the Board explicitly declared that butlgetary and man* power limitations made it impossible to exercise its full power. ${ }^{10}$ The yard sticks were designed to avoid an unmanageable case-load and to provide predictability of jurisdiction. ${ }^{11}$

9. The Board will normally assert jurisdiction if a dispute involves any one of the following:

(a) Instrumentalities and channels of commerce, interstate or foreign. W.B.S.K., Inc., 91 N.L.R.B. 630 (1950).

(b) Public utility and transit systems. Local Transit Lines, 91 N.L.R.B. 623 (1950).

(c) Establishments operating as an integral part of a multistate enterprise. The Borden Co., 91 N.L.R.B. 628 (1950).

(d) Enterprises producing or handling goods destined for out-of-state shipment valued at $\$ 25,000$ a year, or performing services outside the state in which the firm is located, valued at $\$ 25,000$ a year. Stanislaus Implement and Hardware Co., 91 N.L.R.B. 618 (1950).

(e) Enterprises furnishing goods or services of $\$ 50,000$ a year or more to concerns in categories (a), (b), or (d). Hollow Tree Lumber Co., 91 N.L.R.B. 635 (1950).

(f) Enterprises with a direct inflow of goods or materials valued at $\$ 500,000$. Federal Dairy, Inc., 91 N.L.R.B. 638 (1950).

(g) Enterprises with an indirect inflow of goods or materials from out-of-state valued at $\$ 1,000,000$ a year. Dorn's House of Miracles, Inc., 91 N.L.R.B. 632 (1950).

(h) Enterprises having such a combination of inflow or outflow of goods or services, coming within categories (d), (e), (f), or ( $g$ ), that the percentage of each of these categories, in which there is activity, taken together add up to 100. The Rutledge Paper Products, Inc., 91 N.L.R.B. 625 (1950).

(i) Establishments substantially affecting the national defense. Westport Moving \& Storage Co., 91 N.L.R.B. 902 (1950).

Part of the impetus for this type of yardstick came from Congress. See SEN. REp. No. 986 PT. 3, 80th Cong., 2d Sess. 14 (1948), where the "Watchdog Committce," established pursuant to Title IV of the Act, 61 STAT. 136 (1947), 29 U.S.C. $\$ \S 191-7$ (Supp. 1952), stated: "The most obvious approach, if the jurisdiction of the Board is to be clearly defined, is a mathematical one. The number of persons employed and the volume in dollar value in sales to out-of-state customers are facts which may be ascertained with accuracy." Thus, the suggestion that jurisdictional standards be couched in dollar terms came directly from that Congressional group charged with reporting on the administration of the Act. The Committee, supra, at 14, also stated: "The committec believes that small local businesses, retail and service establishments, should not be subject to the act."

For a general review of the application of these criteria, see 16 NLRB ANN. REl. c. 2 (1951) ; Shankin, How NLRB Has Applied Its Jurisdictional Standards, 3 LAy. L.J. 391 (1952) ; Comment, 50 Mrrer. L. REv. 899 (1952).

10. See notes 9 supra and 19 infra. See also testimony of Paul M. Herzog, Board Chairman, Hearings before Cammittee on Labor and Public Welfare on S. 249, 81st Cong., 1st Sess. 174-7 (1949); Hearings before House Subcommittce on Appropriations, 82d Cong., 1st Sess. 1-32 (1951).

11. Predictability of jurisdiction was felt to be particularly important for employers and employees coming under regulation for the first time, so that they could know 
Jolict Contractors Association 2. NLRB "2 throws donlt upun the NLRB's authority to decline jurisdiction, in any part of the building trades at least, when a dispute falls within the federal commerce power. With one judge dissenting, the Serenth Circuit commanded the Board to hear on its merits a secondary boycott complaint. The boycott had arisen from the refusal by union employees of a glazing sub-contractor to work on jobs where preglazed window sash had been installed, thereby forcing the general cuntractor to stop using pre-glazed sash. ${ }^{13}$

The NLRB had faced a dilemma in the Jolict situation. The Taft-IIartley Act had made illegal certain practices particularly prevalent in the cunstruction industry-secondary boycotts. ${ }^{14}$ jurisdictional strikes, ${ }^{15}$ and featherbedding. ${ }^{16}$ But prior to the Act, although recognizing its own power to doal with the industry, the Board had refrained from exercising jurisdiction on the ground that the activities were essentially local. ${ }^{17}$ Now the Board was furced to decide whether Congress intended it to hear all cases inrolving such practices or to apply to the construction industry the same discretionary standards that it used in other industries. In choosing the latter alturnative, a majority of the NLRB recognized that the combined interstate ojerations of the "primary" and "secondary" employers had a sufficiunt absolute effect

beforehand whether they might include a closed shop provision in their contracts. See SEN. REP. No. 986, PT. 3, S0th Cong., 2d Sess. 14 (1048).

12. 193 F.2d $\$ 33$ (7th Cir. 1952), 100 U. of PA. L. Rev. 1261. The Board's decision, refusing to assert jurisdiction, is reported sub mom. Glaziers' Union Local No. 27, 90 N.L.R.B. 542 (1950).

13. Open and pre-glazed sash were purchased and installed by the general contractor. The glazing sub-contractor furnished the glass and labor to complete the glazing on the open sash. When the open sash was not glazed, all work on the project ceased, as lathers, plasterers, painters, plumbers, and electricians refuse to work on jobs after November, if windows are not finished. The general contractor, the secondary employer, was thus faced with the alternative of either using pre-glazed sash and not emrloying union labor, or using union glaziers and foregoing use of pre-glazed sash. Stipulation of the parties before the Trial Examiner, cited in Joliet Contractors Ass'n v. NLRB, 193 F.2d 833, 838 (1952).

The Union's by-laws, Article XVI, section 1, forbade members "to glaze any sash for any building in the course of construction or repair . . . in the warchouse of any glazing contractor. All sash and glazing work must be done on each respestive job site or building." Glaziers' Union Local No. 27, 90 N.L.R.B. 542, 549 (1950). The trial Examiner found the goal of this clause, providing as much work as possible for its members, a legitimate objective. Id. at 554. But the Trial Examiner found further that to use the by-laws and working rules "as an aid in the cuforecnest of a sccordory boycott" was a violation of the Act. Id. at 558 .

14. 61 StAT. 136 (1947), 29 U.S.C. $§ 15 S(b)(4)(D)$ (Supp. 1952). LEGrSLAtItE HiISTORY 1347-70.

15. 61 Stat. 136 (1947), 29 U.S.C. $\$ 15 S$ (b) (4) (A) (Supp. 1952); Minurs 455-67; LEGISLATIVE HISTORY, passion.

16. 61 StAT. 136 (1947), 29 U.S.C. $\$ 158(b)(6)$ (Supp. 1952); Minurs 476-80; LEgISLATIVE HISTORY 1544-5, 1570-1, 1623-4.

17. See note 2 supra. 
upon commerce to give the Board power to hear the dispute. ${ }^{18}$ But as compared with other cases, they felt that the commerce effect was relatively instibstantial. $^{19}$ Although the decision was actually rendered prior to the formalization of the 1950 yardsticks, it was thus grounded upon the same rationale as those standards. Board member Reynolds, however, dissented on the ground that Congress had intended special treatment for the construction inclustry. While recognizing that the Board had discretion to deny jurisdiction, he felt that as a matter of policy it should not restrict its jurisdiction over this industry by the usual commerce criteria. ${ }^{20}$

In reversing the Board, the Seventh Circuit appears to have rested its decision in part upon a policy of special treatment for the building trades. The court supported this portion of its opinion by relying upon sources pointing to repeated references in Taft-Hartley's legislative history to undesirable tactics

18. Brief for NLRB, pp. 17-27, Joliet Contractors Ass'n v. NLRB, 193 F.2d 833 (7th Cir. 1952).

19. Glaziers' Union Local No. 27,90 N.L.R.B. 542,543 (1950). See also Brief for NLRB, pp. 17-27, Joliet Contractors Ass'n v. NLRB, 193 F.2d 833 (7th Cir. 1952). The Board had also stated previously that "the factor of aggregate effect on commerce is relevant in establishing the Board's plenary commerce power under the Act. It is not, however, determinative of the question of whether jurisdiction should be exercised in any given case." William G. Churches, 90 N.L.R.B. 378, 380 n.4 (1950). In denying jurisdiction in a dairy industry case, the Board stated: "In the past, we have concluded that, in cases of this kind, an interruption of such inflow by a labor dispute-though the volume of out-of-state purchases be substantial一would not be likely to have a sufficient impact upon interstate commerce to justify an already burdened Federal Board in expending time, energy, and public funds. In the light of more than 3 years' experience under the amended Act and the Board's current budget and case load, we now conclude that, although it would effectuate the policies of the statute to assert jurisdiction in cases of this kind where the direct inflow is substantial, due regard for these factors requires that we continue to decline jurisdiction where the direct inflow is less than $\$ 500,000$ in value annually." Federal Dairy Co., Inc., 91 N.L.R.B. 638, 639 (1950). See note 9 sutpra.

Over the course of its operation under Taft-Hartley, the Board has adopted the shorthand phrase, "would not effectuate the purposes or policies of the Act," Glazicrs' Union Local No. 27, 90 N.L.R.B. 542, 543 (1950), to take the place of repetitive discussions of the lack of time and money available to handle all matters "affecting commerce." The Seventh Circuit, in the principal case, failed to read behind this encapsulated expression, and thereby overlooked its real meaning. See note 29 infra.

The Board's counting method under the yardsticks in secondary boycotts is explained fully in Jamestown Builders Exchange, Inc., 93 N.L.R.B. 386, 387 (1951), where the Board said: "[I]n determining whether the Board will assert jurisdiction in cases in which secondary boycotts are alleged, we must consider not only the operations of the primary employer, but also the operations of any second [sic] employers, to the extent that the latter are affected by the conduct involved. ... If, taken together, the business of the primary and that portion of the secondary employers' business which is affected by the alleged boycott meet the minimum standards, jurisdiction ought to be asserted." And see Forkosch, NLRB's New Jurisdictional Rule in Secondary Boycotts, 2 LAs. L.J. 247 (1951).

20. Board member Reynolds' dissent in the Joliet case, 90 N.L.R.B. 542,544 (1050), adopts in toto his dissent in William G. Churches, 90 N.L.R.B. 378, 382 (1950). 
in that industry. ${ }^{21}$ But there is actually nothing in the Act's legislative history to suggest that unfair practices in the construction industry were to be treated differently from those in other industries. 22 In fact, other illegal union practices, which cut across all industries-such as coercion of workers or refusal to bargain collectively ${ }^{23}$-are no less important and thus seem entitled to equal priority. ${ }^{28}$

But the Seventh Circuit's major ground for reversing the NLRB was the court's finding that the Joliet boycott actually involved a "substantial" effect upon commerce. ${ }^{25}$ Although only four contractors had been directly affected by this dispute, the court pointed out that the union's unfair practices were in reality aimed at all contractors in the Joliet, Illinois, area. ${ }^{20}$ Then, relying upon cases upholding the NLRB's power to hear disputes because the effect on commerce was sustantial, ${ }^{27}$ the court found that the commerce effect of this dispute was also substantial. ${ }^{2 s}$ By refusing to take jurisdiction, the Board had abused its discretion.

21. Joliet Contractors Ass'n v. NLRB, 193 F.2d \$33, 841, 843-4 (7th Cir. 1953). See notes 1416 supra.

22. Legrslative History makes no mention of the Board's custom of refusing to accept jurisdiction over certain industries. It does, however, male continucd reference to specified labor practices which should be outlawed, such as the secondary boycuttcommon in the trucking industry and garment trades, as well as in the construction industry. But following the 1947 Act, both House and Senate committees expressed approval of the general policy of discretionary refusals. SEN. REP. No. 986, FT. 3, S0th Cong., $2 d$ Sess. $11-14$ (1948) ; H.R. REp. No. 1852, S1st Cong., 2d Sess. 10 (1950).

23. These practices are illegal under Taft-Hartley. 61 STAT. 136 (1947), 29 U.S.C. $\S 158$ (a) (5) (Supp. 1952).

24. Charges of coercion, discrimination, refusal to bargain, and featherbedding, against a union under 61 Star. 136 (1947), 29 U.S.C. $\$ 15 S(b)(1),(2),(3),(5)$ and (6) (Supp. 1952), constituted about seventy-five percent of all union unfair practice charges. 16 NLRE ANN. REP. 297 (1951). The construction industry fell just at the average, with manufacturing slightly above, and mining and transportation slightly below, the average. Figures for the previous years under Taft-Hartley show similar percentage and distribution figures. 15 NLRB ANN. REP. 224 (1950), 14 NLRB Am. REP. 162 (1949), 13 NLRB ANN. ReP. 102 (1948).

25. Joliet Contractors Ass'n v. NLRB, 193 F.2d \&33, 839-40 (7th Cir. 1952).

26. Id. at 839. All such contractors were members of the Joliet Contractors Association-a non-profit Illinois corporation composed of some twenty-two general contractors engaged in the construction and repair of industrial, commercial, and residential buildings, and some forty-four specialty or sub-contractors. The Association includes in its membership two glazing contractors who install glass and perform all of the glazing services in building construction in Joliet and vicinity, generally under sub-contracts with general contractors. Id. at 834 .

27. E.g., Polish National Alliance v. NLRB, 322 U.S. 643, 64S (1944) (insurance); NLRB v. Fainblatt, 306 U.S. 601,607 (1939) (garment manufacturing); United States v. Women's Sportswear Mfrs.' Ass'n, 336 U.S. 460, 464 (1949) (anti-trust injunction granted). Such cases prove only that the Board could, if it chose, regulate these industries -a point which the Board conceded from the outset. Glaziers' Union Local Nio. 27, 90 N.L.R.B. 542, 543 (1950). See note 18 supro.

28. Joliet Contractors Ass'n v. NLRB, 193 F.2d 833, 844 (7th Cir. 1952). 
The court's finding of a substantial effect on commerce would undoubtedly have been correct had the issue been whether the Board had pozver over the dispute. But the Board was concerned only with the relative substantiality of impact of the immediate controversy. This the court failed to recognize; ${ }^{20}$ its opinion rehearses much of the semantic struggling of the Supreme Court a decade ago to sketch the outer limits of the federal commerce power, without meeting the more fundamental problem of the daily implementation of the Act by the Board.

The real problem facing the board is its inability to hear all labor disputes which fall within the legal limits of its authority. ${ }^{31}$ Already burdened with a backlog of 6,000 cases, ${ }^{32}$ the Board, under the Seventh Circuit's interpretation, would be obliged to increase its case-load even further. Cases are now presented to the Board when its General Counsel issues a complaint based on an unfair labor practice. ${ }^{33}$ Heretofore, these complaints have been issued with

29. "The Board makes another argument which we think is without merit. In its brief it states: 'Where the cut-off point will be set depends on a number of factors, which not only fluctuate, but are best evaluated by the Board itself-e.g., the size of the Bontd's appropriation, the number of cases anticipated, the expected proportion of representation to complaint cases, and the concentration of these cases in various industries.'

"None of the reasons thus stated were assigned by the Board as a basis for dismissal of the complaint. It was dismissed upon the Board's conclusion that the impact on come merce was insubstantial." Id. at 844 . But see note 19 supra, indicating that the Board did in fact adopt such a position.

This statement may be seized upon as a convenient escape for a court unwilling to upset the Board's discretionary denial of jurisdiction, where the Board, in its decision, has spelled out these practical administrative considerations. But the statement secms inconsistent with the Joliet court's general view that the Board has little or no discretion to refuse jurisdiction if there is "substantial effect" on commerce in constitutional terms. Cf. the court's statement: "The unfair labor activities shown and found had a substantial effect upon commerce. . . . Such being the case, we think the Board was without discretionary authority to dismiss the complaint." Joliet Contractors Ass'n v. NLRB, 193 F.2d 833, 844 (7th Cir. 1952).

In Progressive Mine Workers v. NLRB, 189 F.2d 1, 4 (7th Cir.), ccrt. denicd, 342 U.S. 868 (1951), the Seventh Circuit itself recognized the fact that the Board must base its decision to act not only on the theoretical conclusion which gives it power, but with cqual regard for its available funds and manpower. In sustaining the Board's refusal to take jurisdiction over a coal mining enterprise, the court noted that "the question [of substantial effect] relates not to the existence of the federal power but to the propriety of its exertion in a given state of facts." See also NLRB v. Atkinson Co., 195 F.2d 141, 144 (9th Cir. 1952).

30. See note 27 sipra.

31. Even under the 1950 standards, supra note 9, the Board has been unable to kcep abreast of its case load. In 1951, the Board was 6,375 cases behind. 16 NLRB ANN. REp. 291 (1951). Similar figures for the years since Taft-Hartley are: $1950-6,714 ; 1949-$ 5,$722 ; 1948-12,642$. Statistics from the NLRB's annual reports for 1950, 1949, and 1948 respectively.

32. Ibid.

33. 61 Stat. 136 (1947), 29 U.S.C. \& 153(d) (Supp. 1952). "[The General Counsel] shall have final authority, on behalf of the Board, in respect of the investigation of charges and issuance of complaints under section 160." 
regard for the Board policy of hearing only important disputes. ${ }^{32}$ In 1 this approach does not seem to have unjustly discriminated ayainst the building trades. ${ }^{35}$ In fact, the Board has declined jurisdiction in unly five of the more

34. Except for the term of General Counsel Goorge N. Denham, July, 1947September, 1950, complaints have been issued only in those matters where it is litisly that the Board will assert jurisdiction. Under the Wagner Act, this policy was facilitated by placing the General Counsel subordinate to the Board. Taft-Hartley, however, separated the prosecution functions of the General Counsel into a separate offec. 61 Srar. 136 (1947), 29 U.S.C. $\$ 153$ (Supp. 1952). But of. Haleston Drug Stores v. NLRB, 187 F.2d $41 S$ (9th Cir.), cort. denied. 342 U.S. 815 (1951) (Euard has final authority to dismiss complaint after issuance). The present General Councel, George J. Eutt, is apparently more willing to abide by the Board's announced jurisdictional poliey than was his predecessor, Mr. Denham. Forkosch, NLRB's New Iturisdictional Rule in Sccondary Boycotts, 2 LAB. L.J. 247, 253 (1951) ; Haleston Drug Stores v. NLRB, stspra, at 422 n.5; Dants, Adamnistrattie Law 406-12 (1951).

For Congressional reaction to Denham's extension of control, see H.R. REx. No. 1852, \$1st Cong., 2d Sess. 10(1950): "It is evident from the size of the Board, and the staff allotted, and the budget considerations adopted by the Congress, that it was not contemplated that the jurisdiction of the agency was to be developed to the untovard degree advanced by the General Counsel [Denham]." See SEx. Rep. No. 99, S1st Cong., 1st Sess. 37-43 (1949) ; Sen. Rep. No. 99, PT. 2, S1st Cong., 1st Sess. S (1949); Hcarings before Subcommittees of Committecs on Education and Lahor, and Expenditures in the Executive Department on N.L.R.B. Goncral Counscl's Interprotation of "Affecting Conamerce," S0th Cong., 2d Sess., 1-44 (194S) ; H.R. REP. No. 2050, 80th Cong., 2d Sess. 1-7 (1948).

35. Although no precise figures are available, the low dollar requirements of the Board's yardsticks do appear to take into account the diversified, small-unit structure of the industry-especially standards (d), (e), (h), and (i), supra note 9. In adlition, computation of the interstate business volume of firms for which construction work is done would bring a great deal of industrial construction within the jurisdiction of the NLRE. See (f), (g), stipra note 9.

Charges that the Board, by its yardsticks, supra note 9, is excluding most of the building trades from regulation rests on an unwarranted interpretation of statistics on the structure of the construction industry. Brief for the Petitioners, p. 57, Joliet Contractors Ass'n v. NLRB, 193 F.2d $\$ 33$ (7th Cir. 1952), claims that \$7.2 Ircreent of the establishments in the industry did less than $\$ 25,000$ worth of business in 1939, thereby implying that the Board yardsticks cover only a small fraction of the industry. That

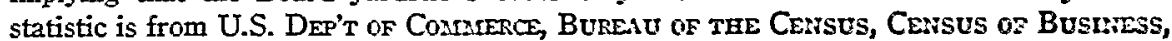
1939, Construction 1939, Vol. 4, pp. 6, 53 (1945).

An accurate estimate of the scope of Board coverage vould have to talie into account current construction costs, and current volume of business. There were about 318,600 firms in the construction industry in 1948. U.S. Dep'T of L.aros, Bunesu of L.aron Statistics, Miaterlals on the Construction Industay, Table $S$ (Oct. 20, 1949). The average expenditures per firm in this industry were more than \$60,000 in 1949. Interpolations from U.S. Dep't of Labor, Bureau of Labor Statistics, Exiperiditures füs New Construction 1915-1950, Table 2 (Aug. 1951). This figure should probably be revised upward for 1952, as total new construction expenditures in 1952 were $\$ 31,025,000,000$, or an increase of 30 percent over 1918. Ibid. Total expenditures for new construction have almost quadrupled since 1939 , rising from $\$ \$, 198,000,000$ in that year to $\$ 31,025,000,000$ in 1951. U.S. Dep't of Laros, ExpendituRes for New Constnct tiun 1915-1950, Table 2 (Aug. 1951), and supplements thereto for 1951. Expenditures for publicly-financed residential building increased 131 percent from January, 1951, to January, 1952. Publidy- 
than seventy-five construction industry matters before it since October, 1950.10 Under Joliet, however, the number of building trades cases could become unmanageable. The only check would be through the policy of the Generil Counsel in issuing complaints. Should such restraint in initiating action also be treated as an abuse of discretion, the Board could not handle important matters promptly without recourse to some sort of priority system. It would then have to allow other matters to languish on the docket, denying effective relief.

Nor is the Joliet holding necessarily limited to disputes in the building trades. The court's demand for Board action in the Joliet case may be read to abolish discretionary jurisdiction in other fields. ${ }^{37}$ Such a construction would revive the confusion that developed immediately after Taft-Fartley was enacted, when the Board attempted to assert jurisdiction beyond its capacity for effective enforcement. ${ }^{38}$ Furthermore, such an interpretation would seriously weaken the power of state labor boards. Post Taft-Hartley cases suggest that state boards cannot hear disputes in areas customarily handled by the NLRB. ${ }^{39}$ Although it is possible that a twilight zone already has been

financed industrial construction was up 130.6 percent in the same period. U.S. DEp'T of Labor, Construction, table 4, p. 7 (Jan. 1952). Public outlay for military and naval facilities jumped 483.3 percent from January, 1951, to January, 1952. Ibid.

36. Plumbing \& Heating Co., 99 N.L.R.B. No. 3 (May 6, 1952); Plumbers \& Pipe Fitters, 95 N.L.R.B. 1480 (1951); Brick \& Tile Co., 94 N.L.R.B. 15 (1951); Hod Carriers Local No. 210, 92 N.L.R.B. 93 (1950); Snohomish County Building Material Ass'n, 92 N.L.R.B. 39 (1950).

37. The Seventh Circuit rests heavily on the following language, which it quotes twice in the course of its eleven-page opinion: "Whether or no practices may be deemed by Congress to affect interstate commerce is not to be determined by confining judgment to the quantitative effect of the activities immediately before the Board. Appropriate for judgment is the fact that the immediate situation is representative of many others throughout the country, the total incidence of which if left unchecked may well become farreaching in its harm to commerce." Polish National Alliance v. NLRB, 322 U.S. 643, 648 (1944).

If this "total incidence" view were adopted by the Board, hotels, bars, laundries, and other local service trades might be included in the area of mandatory Board jurisdiction. Congress clearly did not intend this result. Hearings before Committee on Labor and Public Welfare on S. 249, pt. 4, 81st Cong., 1st Sess. 1659-1707 (1949); SEN. REv. No. 986 PT. 3, 80th Cong., 2d Sess. 14 (1948). And see note 34 supra.

38. In 1948, after a year of operation under Taft-Hartley, and taking virtually all matters presented to it, the Board had a backlog of over 12,000 cases. See note 34 supra.

For an indication of possible Congressional reaction against such a judicial interpretation, see SEN. REp. No. 986, pr. 3, 80th Cong., 2d Sess. 11-14 (1948).

39. Federal jurisdiction in this area is exclusive, and once the Board has regulated an industry, the state board may not thereafter claim jurisdiction. Bethlehem Stecl Co. v. NLRB, 330 U.S. 767 (1947) (NLRB failure to regulate foremen for purposes of certification did not open this area to state action); LaCrosse Telephone Corp. v. Wis. Employ. ment Rel. Bd., 336 U.S. 18 (1949) (although no federal action on case at hand, industry customarily under jurisdiction of NLRB exempt from state regulation). Cf. Penna. Lab. 
created in which the NLRB does not, and the state boards cannot properly, assert jurisdiction, ${ }^{40}$ such local authorities continue to hear cases falling within the potential power of the NLRB.41 But requiring the NLRB to hear all cases over which it could exercise jurisdiction would not only magnify the Board's problem of keeping abreast of its case-load, but would clearly undercut most state regulation. ${ }^{42}$

Aware of its sweeping powers but limited resources, the NLRB seems better equipped than the courts to maximize the effectiveness of the LaborManagement Relations Act. Barring an egregious abuse of discretion, courts should be loath to challenge the Board's jurisdictional decisions. If the building trades require closer supervision than is practical under existing law, appropriate remedies should be sought in Congress.

Rel. Bd. v. Frank, $362 \mathrm{~Pa}$ 537, 67 A.2d 78 (1949) (state may not act if allegations would constitute unfair practices under state and federal acts).

This problem is further complicated by a provision in the Taft-Hartley Act, 61 Srat. 136 (1947), 29 U.S.C. $\$ 160$ (Supp. 1952), which provides that the national board may not cede jurisdiction to a state board unless the state act is substantially similar to the federal legislation in the applicable sections. LegrsLAtrve Hustony 432, 500,550 , 833 , 986, 1052 (1948).

40. For literature on the conflict between state and national boards, sce: Cox \& Seidmann, Federalisin iin Labor Relations, 64 HARv. L. REr. 211 (1950); Smith, The ToftHartley Act and State Jurisdiction over Lahor Relations, 46 MIrcz. L. Ra. 593 (1948); Lorenz, Confict of Jurisdiction betueen National and State Labor Relations Beards, 2 LAB. L.J. 887 (1951) ; Lorenz, Conflitt of Jurisdiction betaces National and Nca Yorl: State Labor Relations Boards, 5 Indus. \& Lab. Rer. Rer. 411 (1952); Ser. Res. No. 985, PT. 3, S0th Cong., 2d Sess. 14-15 (1948).

41. See, e.g., Waterways Engineering Corp., 30 Lab. Rec. Rep. (Ref. Man.) 1105 (Wis. ERB 1952); Wis. Employment Rel. Bd. v. Liquor Salesmen, 29 LAI. REL. REs. (Ref. Man.) 2538 (Wis. Cir. Ct. 1952) ; Milwaukee Sentinel v. Wis. Employment Rel. Bd., 29 Lab. Ret. ReP. (Ref. Man.) 2017 (Wis. Cir. Ct. 1951); Royal Concuurse Co., 29 LAJ. REL. REP. (Ref. Man.) 1085 (N.Y. LRB 1951).

42. See note 39 supra. 